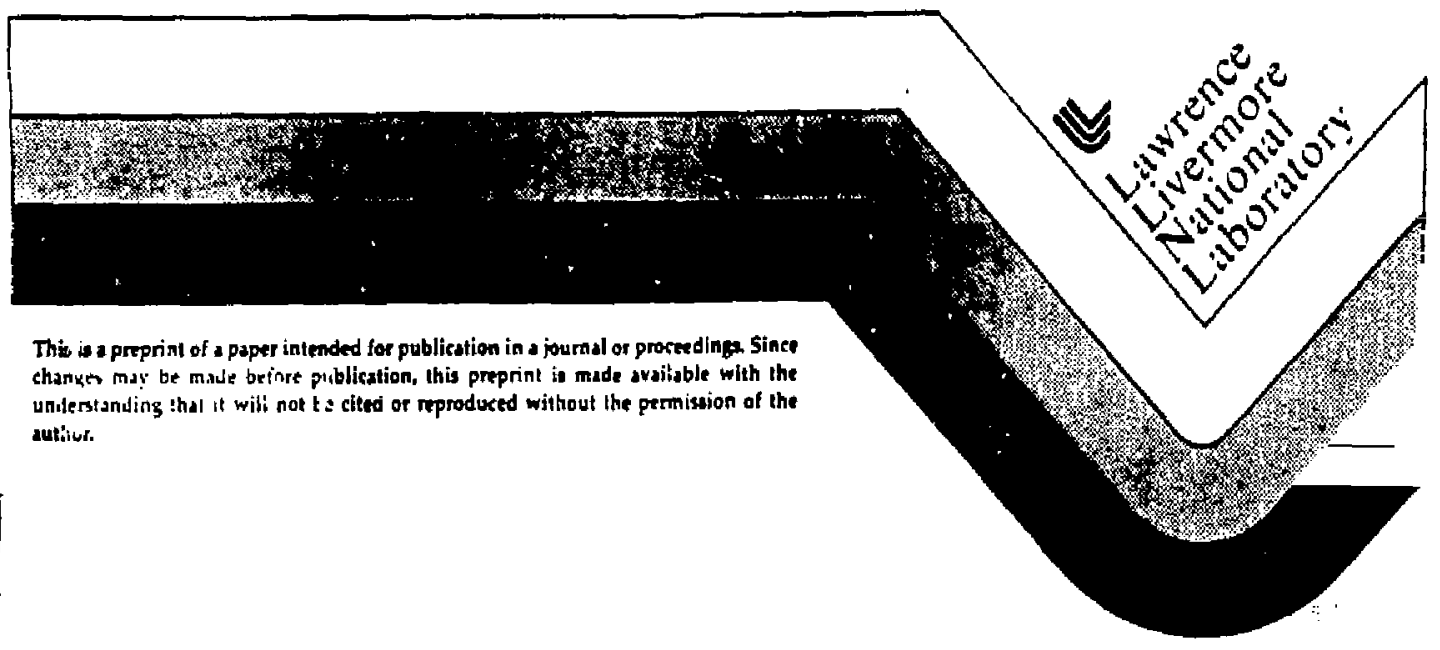




\section{ADDENDUM TO PRELIMINARY DESIGN FOR A PIERCE WIGGLER BEAMSTICK}

Figure 1 presents the magnetic field profile on axis for the proposed VYW-8250N wiggler magnet with a $6 " \mathrm{i} . \mathrm{d}$. hole in the polepiece facing the MIT superconducting magnet. The thickness of the top polepiece has also been reduced from $0.5^{\prime \prime}$ to $0.375^{\prime \prime}$. The "dip" in the magnetic field profile that orcured with the 2" i.d. polepiece has been eliminated, and the field from the viggler solenoid maps smoothly into the fringing field from the $7.4 \mathrm{~T}$ superconducting magnet. The combination of the viggler solenoid and fringing fleld from the superconducting magent produces a uniform $2.5 \mathrm{kG}$ fleld for a length of eight inches. The field amplitude inside the iron for this geometry when the viggler solenoid is not energized is $13 \mathrm{kG}$; hence, with the wiggler energized, the field inside the iron will be vell below $12 \mathrm{kG}$.

The contribution from the superconducting magnet fringing field to the $2.5 \mathrm{~kg}$ flat field is represented by the crosshatched line. The top edge of the wiggler solenoid poleplece occurs at 17.375". The contribution from the superconducting magnet is significant even in the middle of the solenold. The $1 . d$. of the top polepiece can probably be reduced somewhat to improve the isolation of the wiggler fleld from the superconducting magnet, without reintroducing a dip in the field. For the field profile shown in Fig. 1 , the top solenoid coil nearest to the top poleplece carrles only 38 A of current, as opposed to the $46 \mathrm{~A}$ of current for the 2" $1 . \mathrm{d}$. polepiece. Hence, the top polepiece i.d. can be reduced to increase the shielding, and the currert in the top coll increased to maintain the untform field profile.

The fringing field from the MIT $7.4 \mathrm{~T}$ superconducting magnet is remarkably similar to the fringing field from the 10 T Bitser magnet. The viggler solenoid design presented in Fig. 1 will work equally well with the Bitter magnet; a smooth field profile can be produced with only minor changes in the viggler coil currents near the top poleplece.

Two results of this investigation call for further work. Pirstly, the coll currents that MIT provided for the superconducting magnet prrduce a $7.4 \mathrm{~T}$ field according to our calcuiations rather than the 6.51 fleld indicated by MIT. Th1s discrepency should be resolved. our calculations were done with an analytical calculation (AIRCORE) which has alvays given very accurate results in the past. I vonder if MIT inadvertantly prov!ded the coll currents for $7.4 \mathrm{~T}$ (i.e. upper limit of the magnet with pumping on the helium reservoir) which they have been contemplating. Secondly, as indicated schematically (neither the amplitude nor the shape should be accepted as accurate) by the open circles in $\mathrm{Fig} .1$, the fleld increases rapidly again outside the shielding at the gun end of the viggler solenoid. Hence, shielding will also be needed around the gun to isolate the cathode from the superconducting magnet fringe fleld. We recommend that a small coll be Installed inside this gun shielding in order to adjust the focusing of the electron beam in conjunction with the viggler coil closest to the gun.

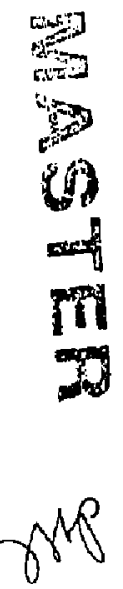




\section{Froposed Vrin-g2soh Electromognet}

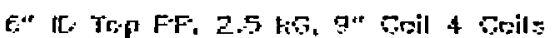

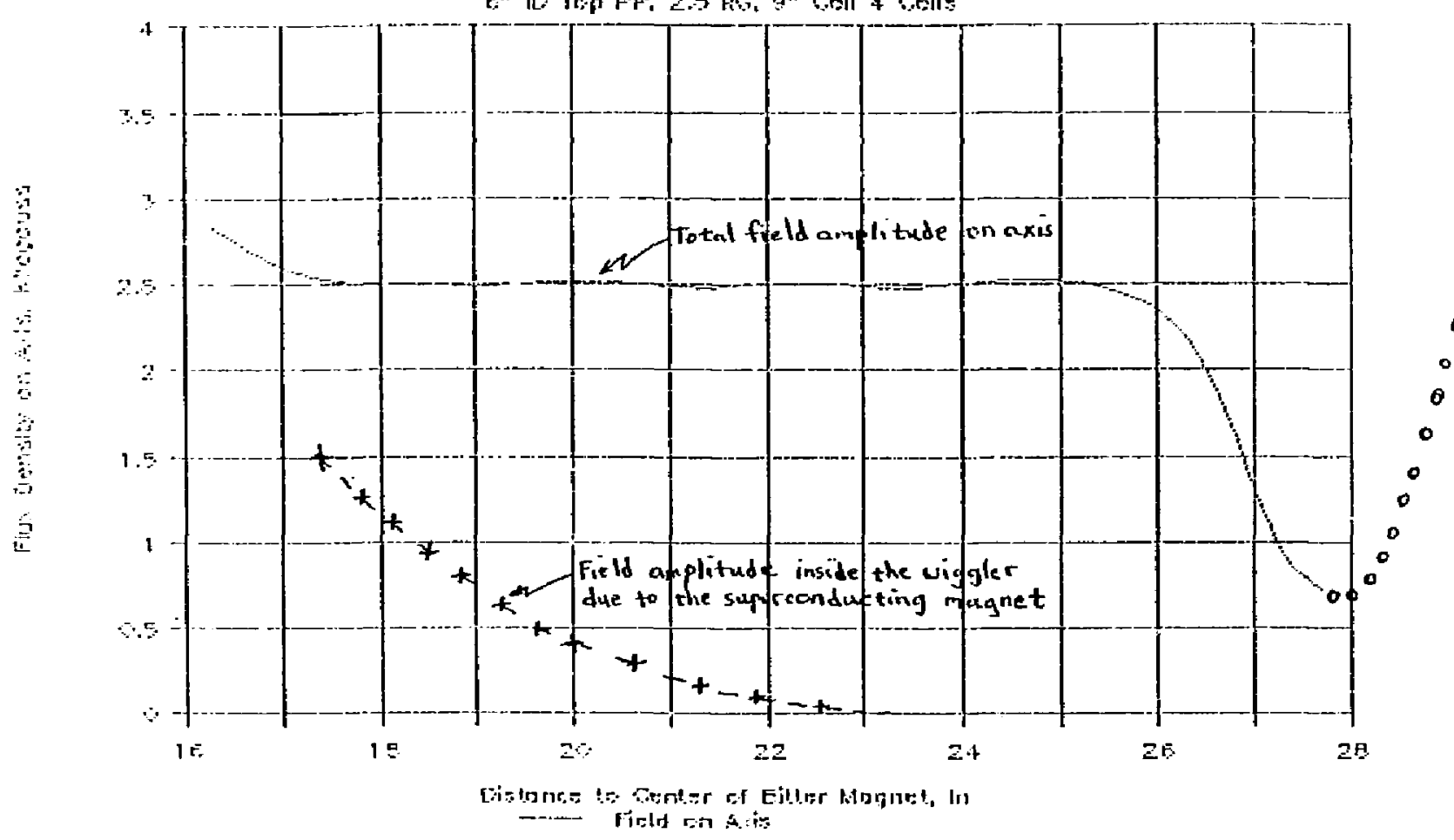

$$
0_{0}^{000000000}
$$

o Onghematic representiation
that the field rises rapidly (up to a peak of $4 \mathrm{kG}$ ) cutside the gun end of the sckelvid. Cigncre the detailes shape, it is not accurate; hound drawis from a verbal descriptian). 


\section{ENEROCUCT:OS}

Lawrence ivecnore National Labotatory is developing a fast turabia microwave source fo: operation a $250 \mathrm{GHz}$ and $10 \mathrm{~kW}$ peak output povet. This repo:t presents the preliminary design of a pierce gun and solenoid magnet that will be campatibie with a Pjerce-wiggler electron beam formation system (beanstick). The beamstick will be an appropriate power source for a cunable gyto-bHO at 250 Gllz. Figure 1 presents the major components of the Pierce-nigglel beamstick: the electron gun, solenoid, bean tunnel, riggler, and vacuum valve. Figure 2 shows an artistic conception of how the beansick will interface it th the interaction magret, modulator and gyro-Bho circuit at MIT.

\section{SOLENoIJ}

During the course of this design, we realized that the wiggler solenoid incecacts strongily with the fringing fleld of the interaction thagret. Designing the proper magnetic field profile frcm the wiggler solenold to the interaction cilcuit will tequite a significant design effort involving close cooperation between Varian and MIT. Table 1 lists the design goals and achieved design parameters for the wiggler solenoid. Figure 3 shows the magnetic field profile for the current design at 2800 Gauss on axis. The field is uniform within approximateiy $1 \%$ over a $6 "$ length. The 2800 Gauss amplitude represents the "ietuned" condition when the magneric field is purposely set to be off resonance. We expect 2800 Gauss to be the highest on-axis magnetic field produced by the wiggle: solenoid under normal operating condicions. The cross hatched line in Fig. 3 shows the field amplicude ai a radius of $0.94 "$ " corresponding to the location of the magnetic wiggier strip furchest off axis. The field strength a this radial position is stili under $3 \mathrm{kG}$; the magnecic wiggler strips start to demagnetize significantly in axial Eields over $3 \mathrm{kG}$.

The viggler solenoid design consists of four pairs of incependently concrollable coils. Each pai: of coils is connected together internally with pover leads urought out. Hence, the fleld profile can be controlled to optimize the electron beam formation and foclising.

The current solenoid design calls for iron shielding. The shielding must be extia thick in order to prevent sacuration of the iron in the exiensive zainging fields of the Bitter magnet used for the inceraction circuit. The icon shielding has several consequences, some desirable, sone not. One desirable consequence of the shielding is isolation of the wiggler axial field fion the interaction circuit fieid. Hence, the interaction circuit field can be modified without affecting the resonance in the wiggler. hlso, the shielding protects the riggle: and cathode Eron stray magnetic lields. This protection may be important, since the cransverse fields in the wiggler are only 10 Gauss. On the other hand, the iron shielding adds $40-50$ pounds extca weight over that is required for structural integrity. Also, preiliminary calculations indicate that the iron may increase the compressive fazce between the wiggler solenoid and the Bitter magnet 
by up to a factor of five.

The current shieldiag design needs some modification because the shieiding causes a "dip" in the wagnetic field amplitude between the riggier solenoid and the Bitrer magnet. He feel that the dip can be elininated by trirning the polepiece facing the Bitter magnet, and by enlarging the hoie in that polepiece.

other detais of the solenoid design are presented in appendix $h$.

\section{VACUUM BELL VHLVE}

He have identified a bail valve design capable of isolating the ?iezce-wigeler vacuum and yet compact enough to fit through the bore of the wiggles. Figure 4 displays matketing literature for a vacuum ball valve that meets the vacuum requitements of our application. The custom ball valve being constructed by Hunsington vechanical Laboratories will be based on a similar design; hovever, it will incorporate material which can withstand higher bakeout cemperature and will be smaller diameter. The ball valve is scheduled to be delivered in hate april, so we will have an opportunity to evaluate it. If the ball valve seens unsatisfactoty, it will be possible to incozporate a standard gate valve or straighi-through valve and stj!? deliver the gun in June.

\section{GUN}

Tabla 2 lists the specifications for the electron gun. The electrostatic design of the electron gun is virtually complete. Figure 5 shows the simulated electron trajectories for the present design. The design has a microperveance of 0.276 compared to a spectfication of 0.272 . The beam waist is 80 mils diameter, which is slightly smaller than the specified diameter of $100 \mathrm{mils}$. In our experience, the computer simuiations consistently predict a smaller beam diameter than the beam analyzer measures. Hence, ve expect that this electrode design will produce a beam diameter much closer $10100 \mathrm{mils}$ than is indicated by the computer sinulation. Some minor changes will be made to the anode to bring the voltage gradients into the $80.100 \mathrm{~kW} / \mathrm{cm}$ range, which is practical for the short pulse length applicarion of this gun. in six amps beam current, the cathode loading is $5 \mathrm{~A} / \mathrm{cm} 2$, which is consistent with over 1000 hours of cathode life. He are presently designing the magnetic focusing; we won't be able to assess the beam ipple until this design is complete. We expect to achieve a magnetics jesign on the computer with zero ripple; novevel, similar to the situation with the computer simulations of the electrostatic beam waist, we also expect co measure some ripple on the beam analyzer.

The electron gun design incozporates two SAES getters and a Vacion appendage pump in order to help mainiain high vacuum in the gun, wiggler, and gyro-BkO beam runnel.

\section{HIGGLER AND BEAH TUNNEL}

Figure 6 shows the prelininary wiggler and beam tunnel design. The bean tunnel inner diameter must be chosen to compronise between maximizing vacuum conductance and preventing if interaction in the beam tumel. hi 2800 Gauss, the relativistic cyclotron frequency is $7.1 \mathrm{GHz}$ for a $55 \mathrm{kV}$ electron bean. In our experience, if the cut-off frequency for the fundamental mode is $20 \%$ above the syclotron frequency, no $\overline{6} y=0$ zaon interaction will occur in the beam runnel. Hence, the beam 
tunnel should have an i.d. of 0.82 " or less in order to prevent possible gyrotron interaction. Fortunately, this diameter is not a significant consiriction on the vacuum canductance.

For obtaining the best beam quality, the radius of the wiggler should be comparable to the pitch of the viggler helix, in this case about $0.67 "$ ". For larger radius to pitch ratios, the transverse field of the viggler develops amplitude "spikes" at the ends of the viggler. For smaller radius to pitch ratios, the transverse field from the wiggler becomes less uniform across the diameter of the electron beam, which contributes to velocity spread. To a large extent, amplicude end spikes for large radius to pitch ratios can be eliminated by tapering the layers of magnetic strips. For example, the strips can be wound with the first layer having 5 pitches, the second layer with 4.5 pitches and the third layer with 4 pitches. The viggler diameter of 1.5" (0.75" radius) is in the right range for good beam quality and is still large enough to slide over the 1.5 " diameter vacuum valve. In our experience, when the wiggler strips are wound on a 1.5" diameter, they produce about five Gauss transverse field on axis. The strips become uniformly demagnetized about 20\% in an axial field of $3 \mathrm{kG}$. Hence, to get 10 Gauss transverse fleld on axis, about three wiggler strips will be required. The present design cas accommodate five strips if necessa:y.

\section{SCHEDULE}

Tigure 7 presents a milestone chart for delivery of the vot -8250 beamstick. We are making every effort to deliver the beamstick by the lirst week of June 1988. Hovever, everything nust work within specifications the first time in order to meet this delivery date; we have made no provision for contingencies. In particular, very little test time has been alloted for magnetic beam analyzer tests. We should not take shortcuts on these tests because they determine what measures should be taken to improve the beam ripple. Although we will continue to target delivery for the first week of June, a delivery for the third week of June would be more realistic and would have lower overall technicai risk. 


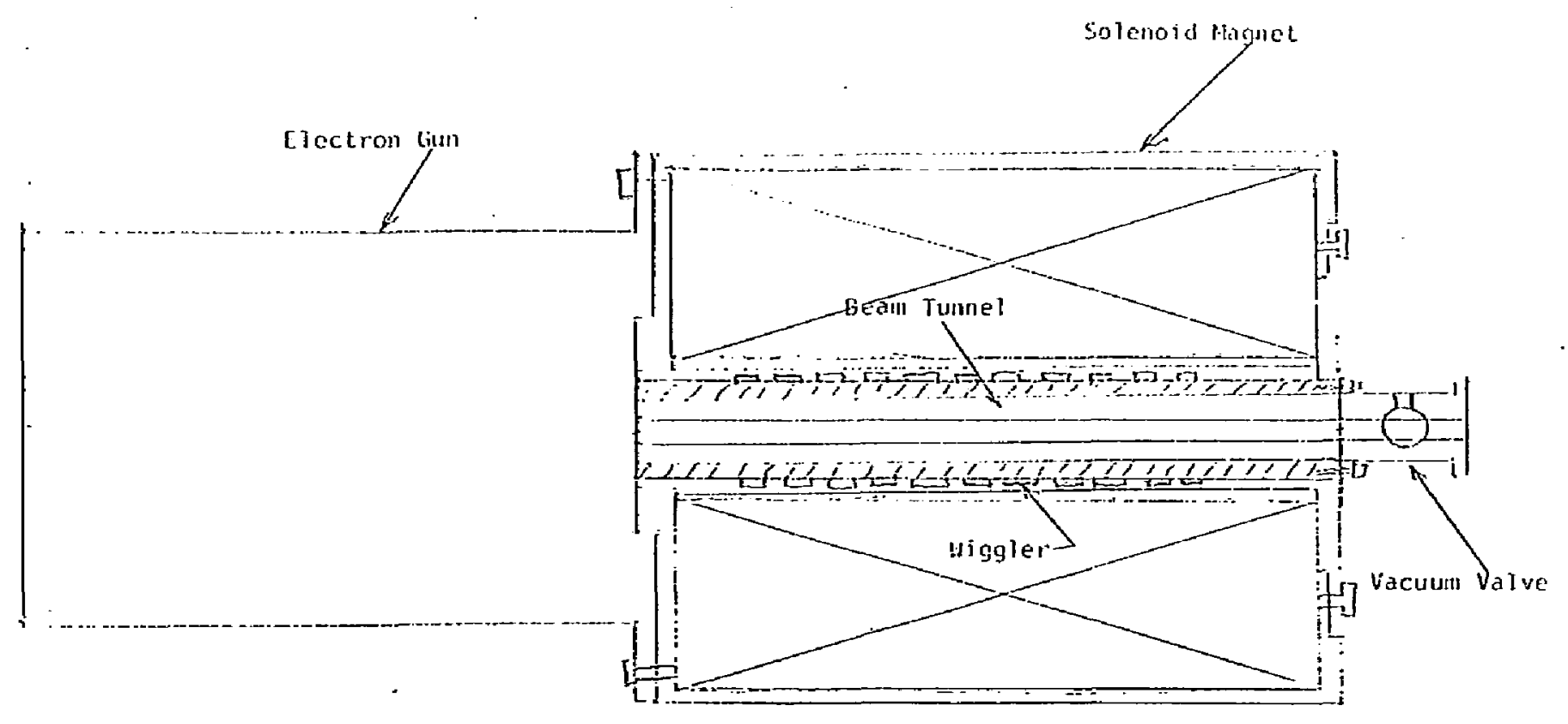

Figure 1. Schematic layout of Pierce-wiggler electron-beam formation systen 


$$
\text { scale } \approx l^{\prime \prime}=10^{\prime \prime}
$$

Modulator

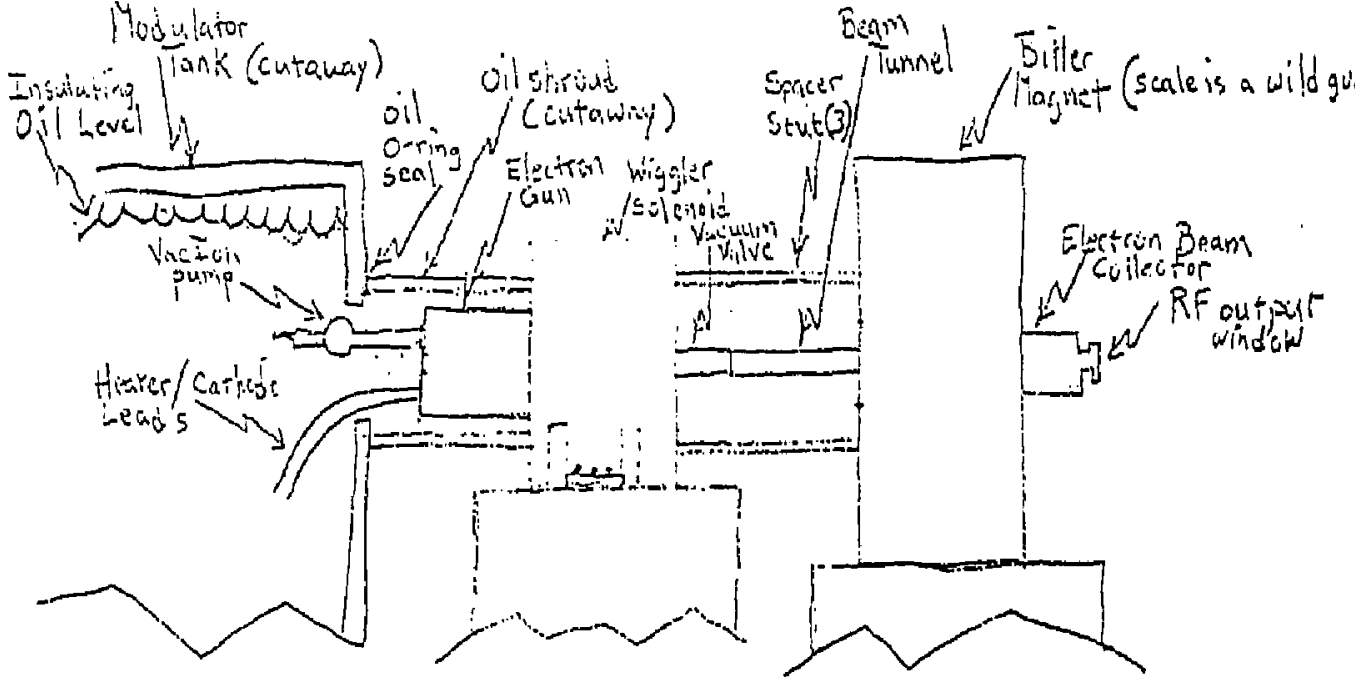

Remivacie split

$$
\text { Scale } \approx 1^{\prime \prime}=5^{\prime \prime}
$$

pole piece (may bi magnetic or not)

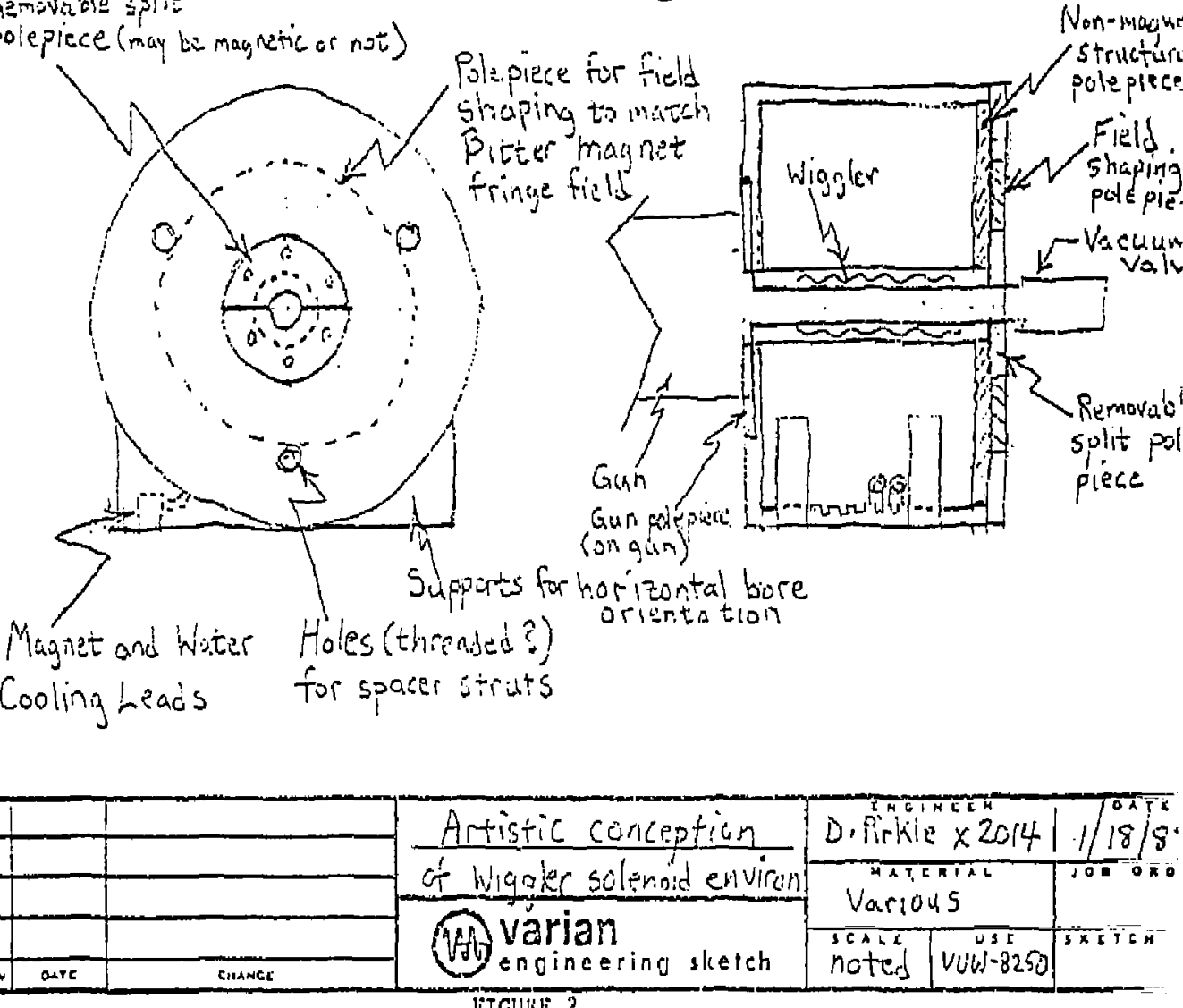

FIGURE ? 


\section{Design Parameters}

Parameter

Operating Field $\mathrm{E}(\mathrm{F} \times .94, \mathrm{Bmag} \times 2.8 \mathrm{kG})$ inside Diamete?

Length

Outside Diameter Power

Current

Weight

Coils

MAndereon, 2/88
Goa!

$2.5 / 2.8 \mathrm{kG}$ $3.0 \mathrm{kG} \operatorname{Max}$ $1.95^{\prime \prime} / 2.25^{\prime \prime}$

9.0" $\operatorname{Max}$

$42 \times$

$2.5 \mathrm{~kW}$

$450 \mathrm{AdC}$

455 Lbs

Not Spec'd
Achicved

$2.5 / 2.8 \mathrm{kG}$

$3.0 \mathrm{kG} \operatorname{Max}$

Fole Piece $\times 1.95^{n}$

Cojl ID $=2.0^{*}$ 10.25" Nom (Reg'd for Field Speo) $10^{n}$ Nom

$2.9 \mathrm{~kW} \operatorname{Max} @ 2.5 \mathrm{kG}$

$3.7 \mathrm{~kW}$ Max $62.8 \mathrm{kG}$ 46.0 Ado@2.5 kG $51.5 \mathrm{Adc} @ 2.8 \mathrm{kG}$ 128 Lbs (Has a 96 Lb Shell) 4 Individual Coils 
Proposed VYW-8250W Electromagnet 2" ID, 2.8 kG, 9" Coil Length, 4 Coils

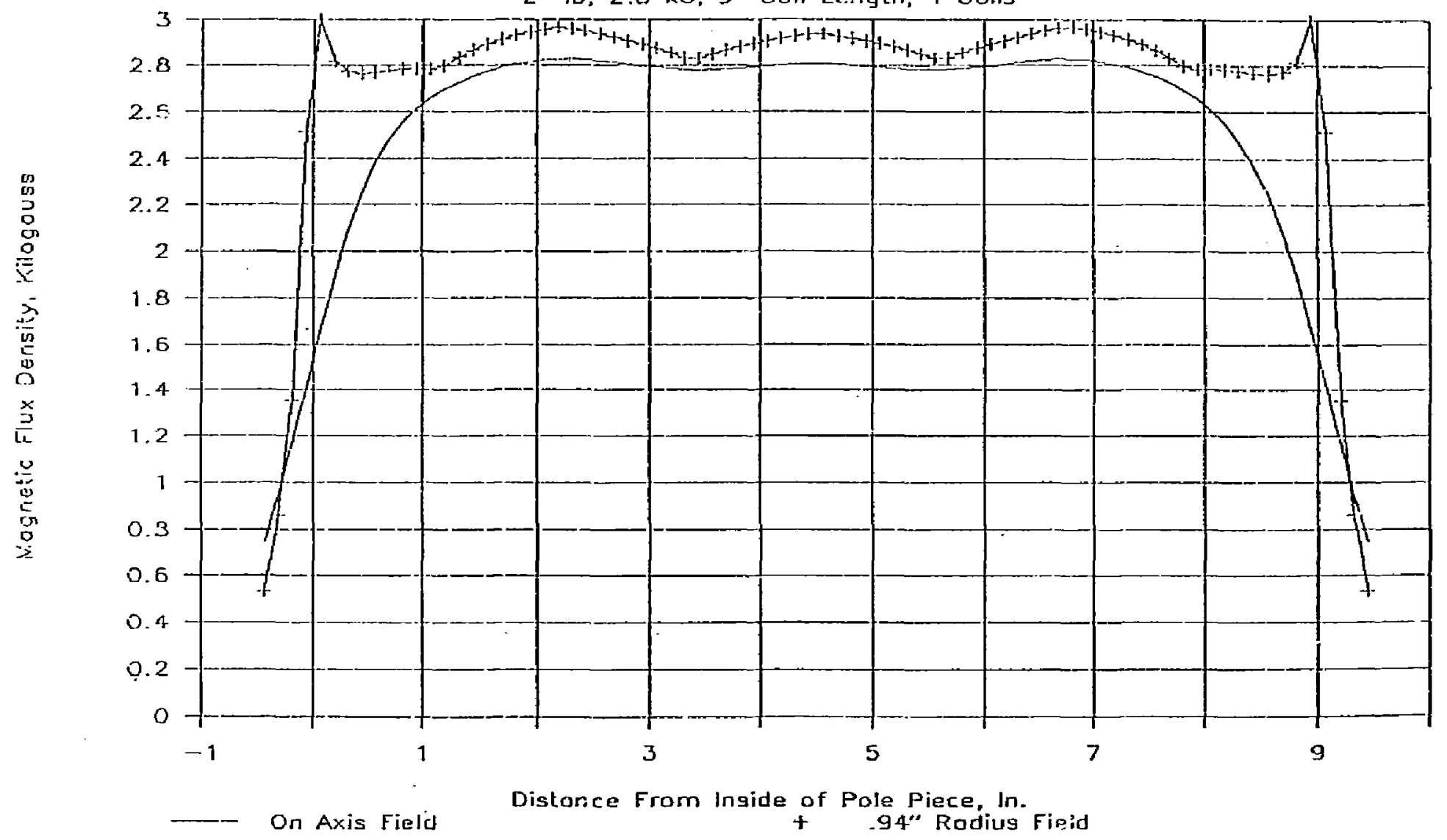




\section{High Vacuum BALL VALVES}

- gJaranteEd leakage rate

- high cONDUCTANCE

- STRAIGHT THROUGH FLOW

- complete RANGE OF SIZFS

- SIMPLE \& EASY TO SERVICE

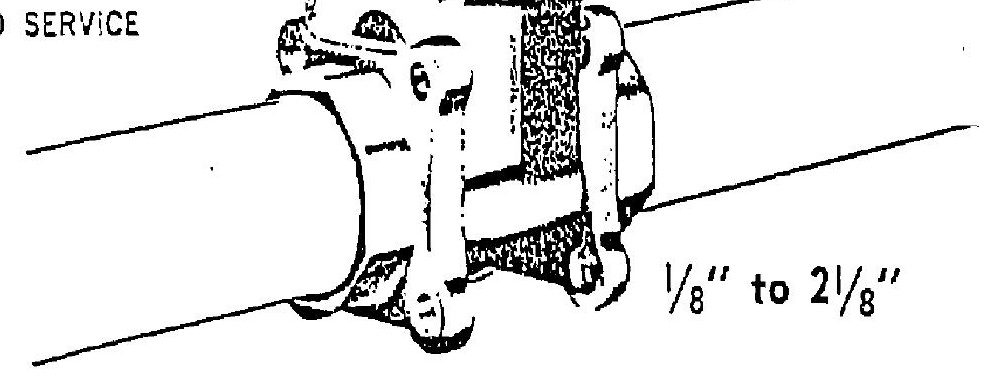

For the first ime a ball valve is cliferec specifically irikenced lor nigh vacuum service. vaives are slotheo in lorjug grass and 304 Sianiess 5ieel in 1/" $102 \%$ " pipe threjo and tube 0.0 . end conricctions. Fillon sobis and Vilon seais are stancard, nowever, other combinations are avoll. able on itquesl.

the valves oller siroighterteugh llow providing maxiflium conduciance. interchangeable end connections, unobstrus. ied poris aliowing leed through and low inifial insiullution and mainteriance cosis.

Jas enirapment has been elimiadice by arilting a hole in the shupolt side of the ball exposing the body cavily to eitiner usiteam or downstream orossure cepending on insialiation. A lurther advantage is the rigid stem assembly which ooes awsy with the lateral movement that pras plogucd users of elher values in the past.

Stum seals are cosily replaced without removing the valve lion the ling and only threp bolts need be dissssembled to scrvice the seats and body seals.

Provision is made to evacuate the arsa between the seat and the body up to the body seal.

Each volve is mass spectrometer helium leak chocked and ceriticd. Guaranteed leakage rate is less than $1 \times 10$. sid. Ce/ses.
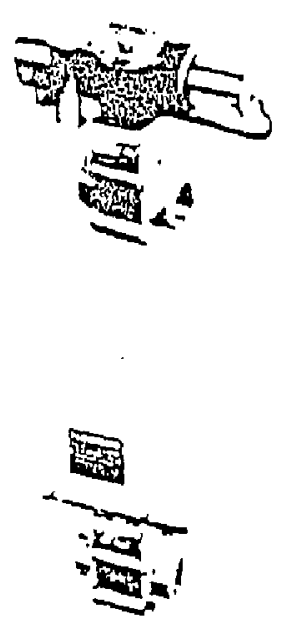

\section{Pneumatic \& Electric ACTUATORS}

PNEUMATIC ACTUATORS. Integrally.mounied valve operators using plani air source are avalable in either a double action or lail-safe design, A 4.way solcroid valve, ether general purpose or explosion. proot, is normatly mounied on the actuator to conirol the air supply. $A$ conirol to regulate the closing speed of the actuater is a part of the soienoid. Compaci microswich assembiles are available where remole indicution o: valve position is desared.

ELECTRIC ACTUATORS. i compacl eleciric molor (brushless) aclualor ... provides posilive vaive operaison. plus maicrally lower installation cast. Only electic parer is necded. Vaive openng or elosing is a matter of 5.6 seconds. Eleciricaliy-actuated unils are supplied in weather.proof housings. Wicroswich assemblies are also avalable where romole indication of valve postion is desired 


\section{TABLE 2. ELECTRON GUN SPECIFICATIONS}

PARAMETER

Bean VoI:age

Beam Current

Micro-perveance

Beam Diameter

Scalloping

Brillouin Number

Duty Facior

Pulse Widch

Repetition Rate

Cathode Life
SPECIFICATION

$60 \mathrm{kV}$ nom. $80 \mathrm{kV}$ max.

4 A nom. 6.2 A max.

.272

.100 inches max.

$8 \% \max .<5 \%$ goal

2.7 .4 or greater

17 $\max$.

1 microsecond; goal of 5 microseconds with aging

$10 \mathrm{kHz}$ mex. (rep. rate $x$ pulse width not to exceed $1 \%$ duty)

1000 bours nom. 


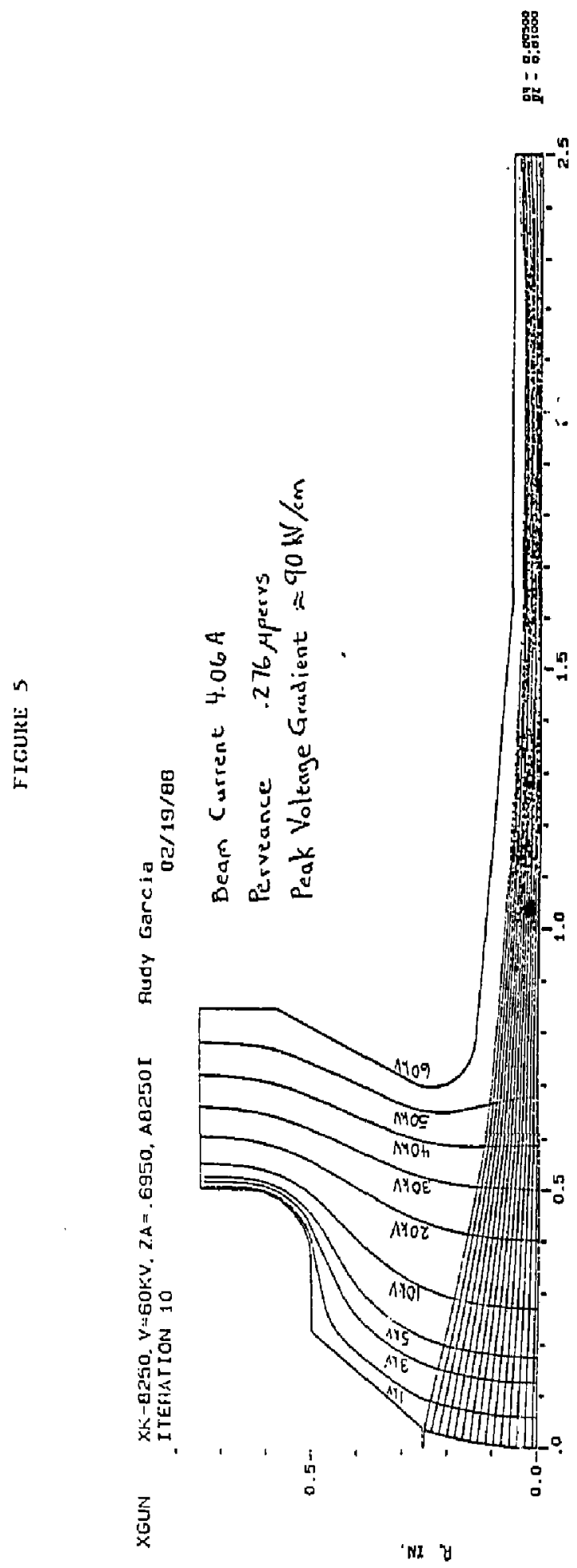




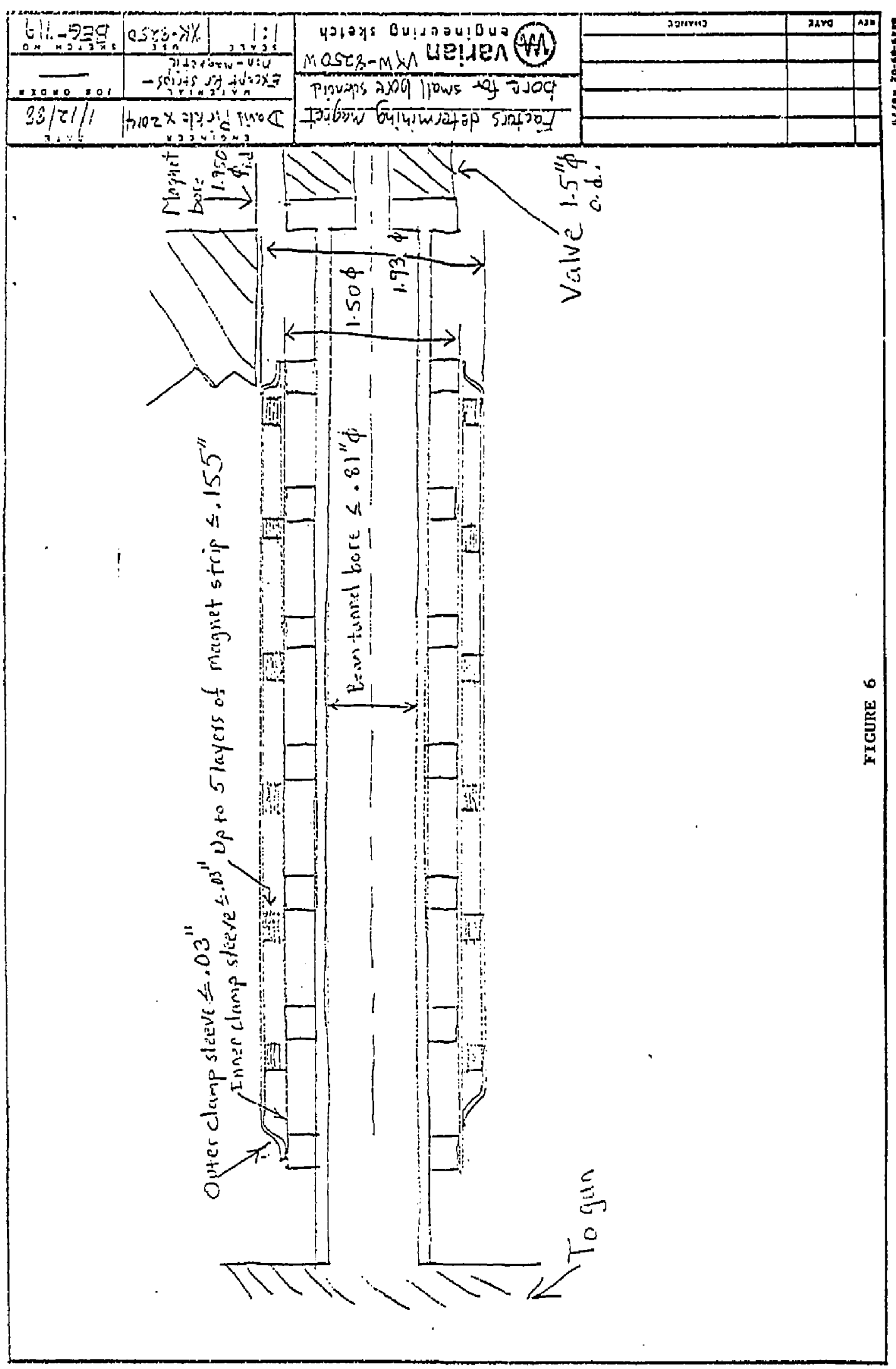




\section{varian $\oplus$}

\section{MILESTONE CHART}

PHOGRAM

DESCAIPTION

1.0 Wiggler Solenoid

1.1 Magnetjcs Mesign

1.2 Mechanical Design

1.3 Tooling

1.31 linding

1.32 Assembly

1.4 Solenoid Parts

1.5 Winding

1.6 Assembly/Test

1.7 Deliver Solenoid

2.0 Electron Gun

2. 1 Layout

2. 2 Decailed Design

2.3 Parts Fab \& Procure

2. 31 Cachode

2.32 H.V. Geramic

2. 33 Piece Parts Fab

2.4 Engineering Gu

2. 41 Fab. Engr. Gun

2.42 Electrostatic Beam

2. Analyzer Test

0.42 Magnetic Beam Analyzer

2.5 Finalize Design
FIGIURE ?

\begin{tabular}{|l|l}
\hline$J 08$ No. & $\begin{array}{l}\text { DAIE } \\
\text { InkCh 10,1988 }\end{array}$ \\
\hline
\end{tabular}

START DEVISEO STANT

$\nabla$ Onig.complete $\triangle$ heVistíc cohplete

$-\forall A$ COMPLETEU MILEstones

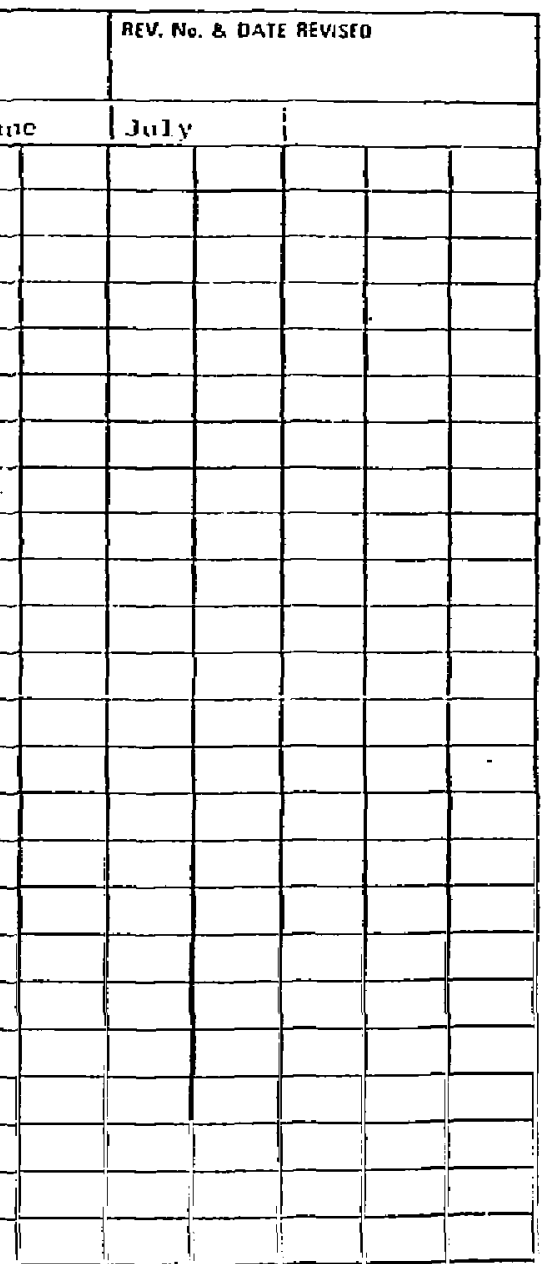


varian(1)

\section{MILESTONE CHART}

\section{progran,}

CrRo- HAO H!AMTICK

\section{DESCRIPTION}

3.0 System Inlegration

3.1 Svslem Desirn.

3.2 Vacuurn Valve

3.3 Evaluate Vaculatin Valve

3.4 Anode-Ee an Tunnel

3.5 Dress Hardware

3.6 Magnetic Shielding

3.7 wigeler

3.8 Test-Solenaid \& Wigridr

3.9 Process GuI

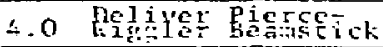

5.0 Set-up at MIT
FI GURE?

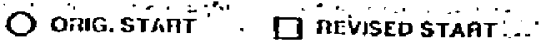

$\nabla$ OHIG.complite $\triangle$ REVISED complete

$\otimes$ A A completed milestones

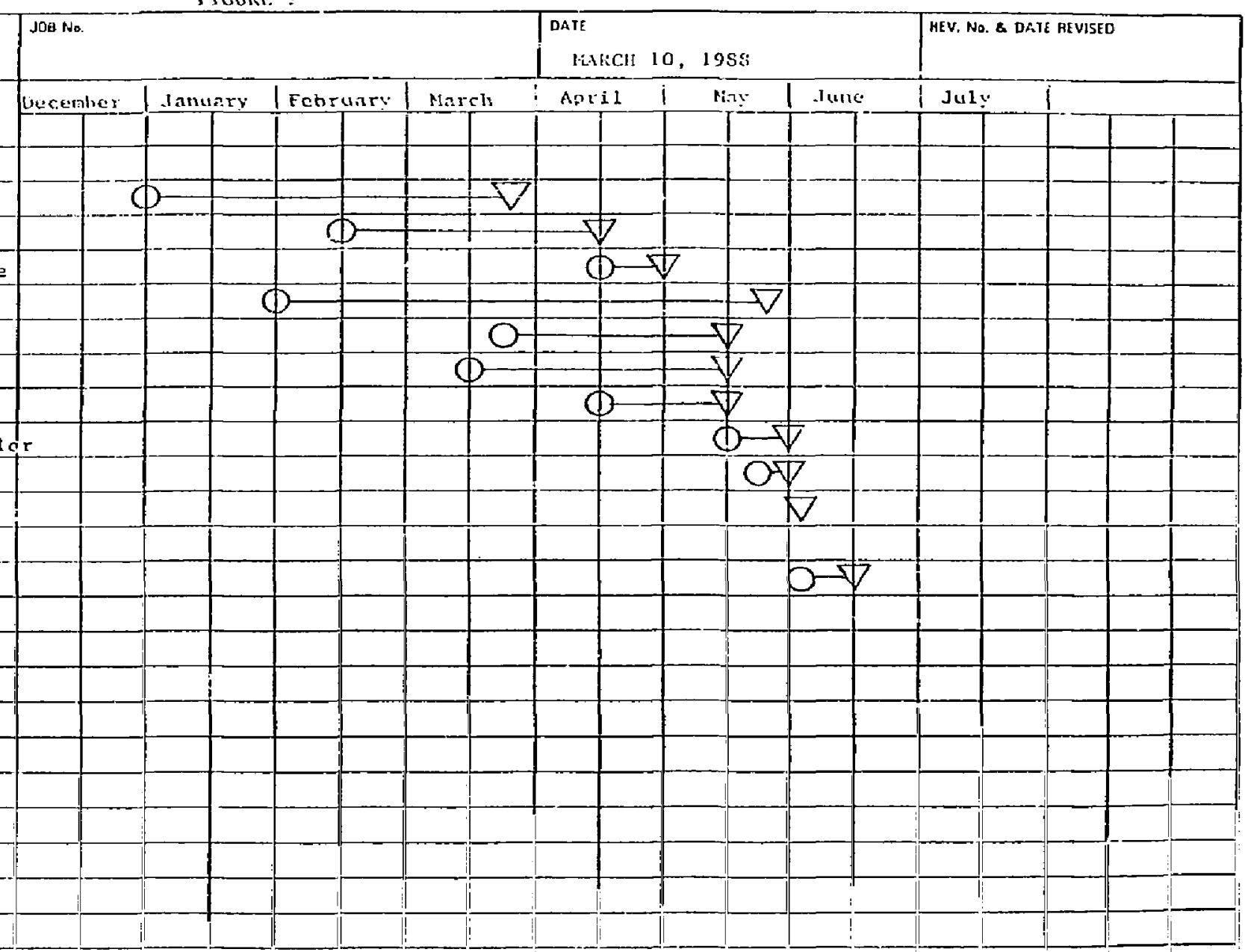




\section{DESIGN PHASE}

- Interior Field

Central Field Homogeniety

$0.94^{\circ}$ Ofi Axis Field Strength

Coil Operating Parameters

- Exterior Field

Bitter Magnet Model

Magnet Sheil Design

interior Field Homogeniety

- Interior/Exterior Crossover Region

Downstream insert Diameter Selection

M Andersan, 2/a8

APPENDIX A 


\section{MECHANICAL DESIGN Construction Methods}

- Coils

Aluminum Foil

Water Cooled

Eight Pies, Four Coils

- Cooling

Water Cooled

OFHC Copper Cooling Plates

37 Deyree Cooling Fittings

- Outer Sheil (Shielding Jacket)

Steel End Pole Pleces

Steel Outer Shell

Kulka Terminal Strip

$M$ Anderson, $2 / 8 B$ 
Design Parameters

\begin{tabular}{|c|c|c|}
\hline Parameter & Goal & Achieved \\
\hline Operating Field & $2.5 / 2.8 \mathrm{kG}$ & $2.5 / 2.8 \mathrm{kG}$ \\
\hline$B(F \times .94, \overline{L m a g} \approx 2.8 \mathrm{kG})$ & $3.0 \mathrm{kG} \operatorname{Max}$ & $3.0 \mathrm{kG} \operatorname{Max}$ \\
\hline inside Diameter & $1.95^{*} / 2.25^{*}$ & $\begin{array}{l}\text { Fole Plece }=1.35^{\prime \prime} \\
\text { Coil ID } 2.0^{n}\end{array}$ \\
\hline Length. & $9.0^{n} \operatorname{Max}$ & $\begin{array}{l}\text { 10.25" Nom (Reg'd } \\
\text { tor Field Spec) }\end{array}$ \\
\hline Outside Diameter & $412^{n}$ & $10^{\prime \prime} \mathrm{Nom}$ \\
\hline Power & $2.5 \mathrm{~kW}$ & $\begin{array}{l}2.9 \mathrm{~kW} \operatorname{Max} @ 2.5 \mathrm{kG} \\
3.7 \mathrm{~kW} \operatorname{Max} \odot 2.8 \mathrm{kG}\end{array}$ \\
\hline Current & $\measuredangle 50$ AdC & $\begin{array}{l}\text { 46.0 Adc @2.5 kG } \\
51.5 \text { Adc @2.8 kG }\end{array}$ \\
\hline Weight & ‘55 Lbs & $\begin{array}{l}126 \text { Lbs (Has a } \\
96 \text { Lb Shell) }\end{array}$ \\
\hline Coils & Not Spec'd & 4 Individual Coils \\
\hline
\end{tabular}

M Anderson, $2 / 88$ 


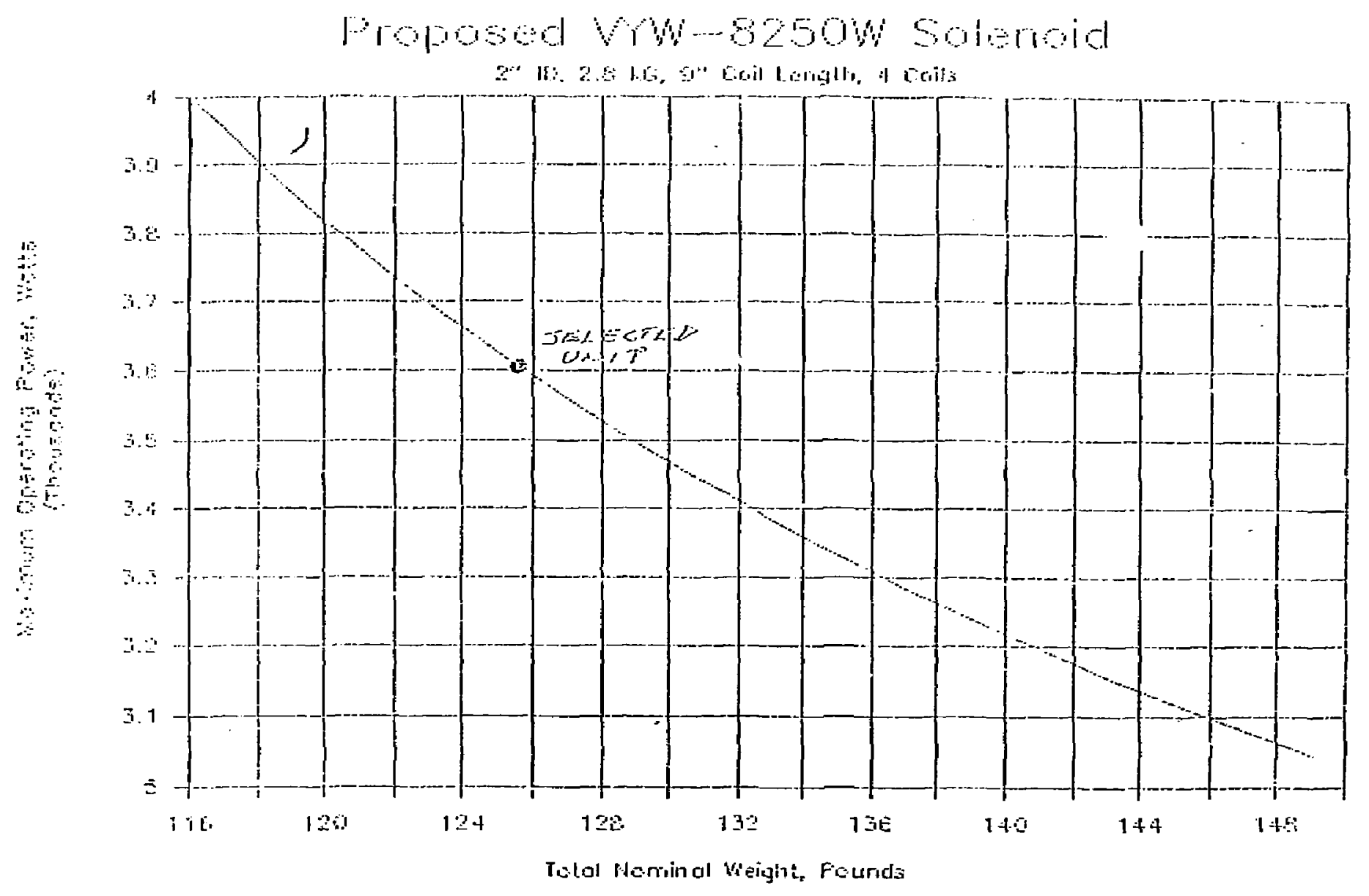


Proposod hy-9250h Solenoid

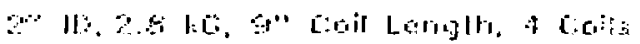

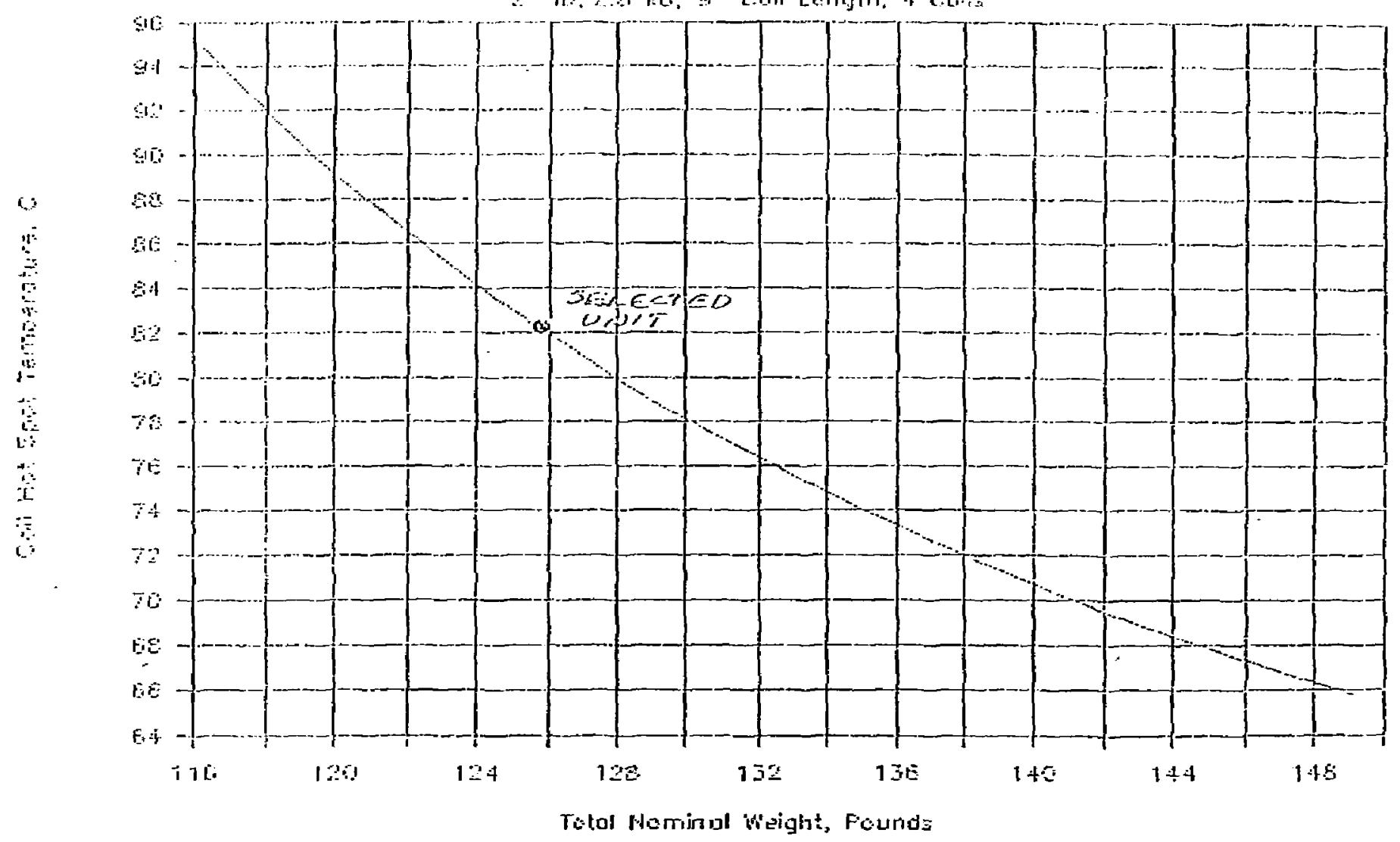




\section{Proposed VYW-8250W Electromagnet}

2" ID, 2.8 kG, 9" Coil Length, 4 Coils

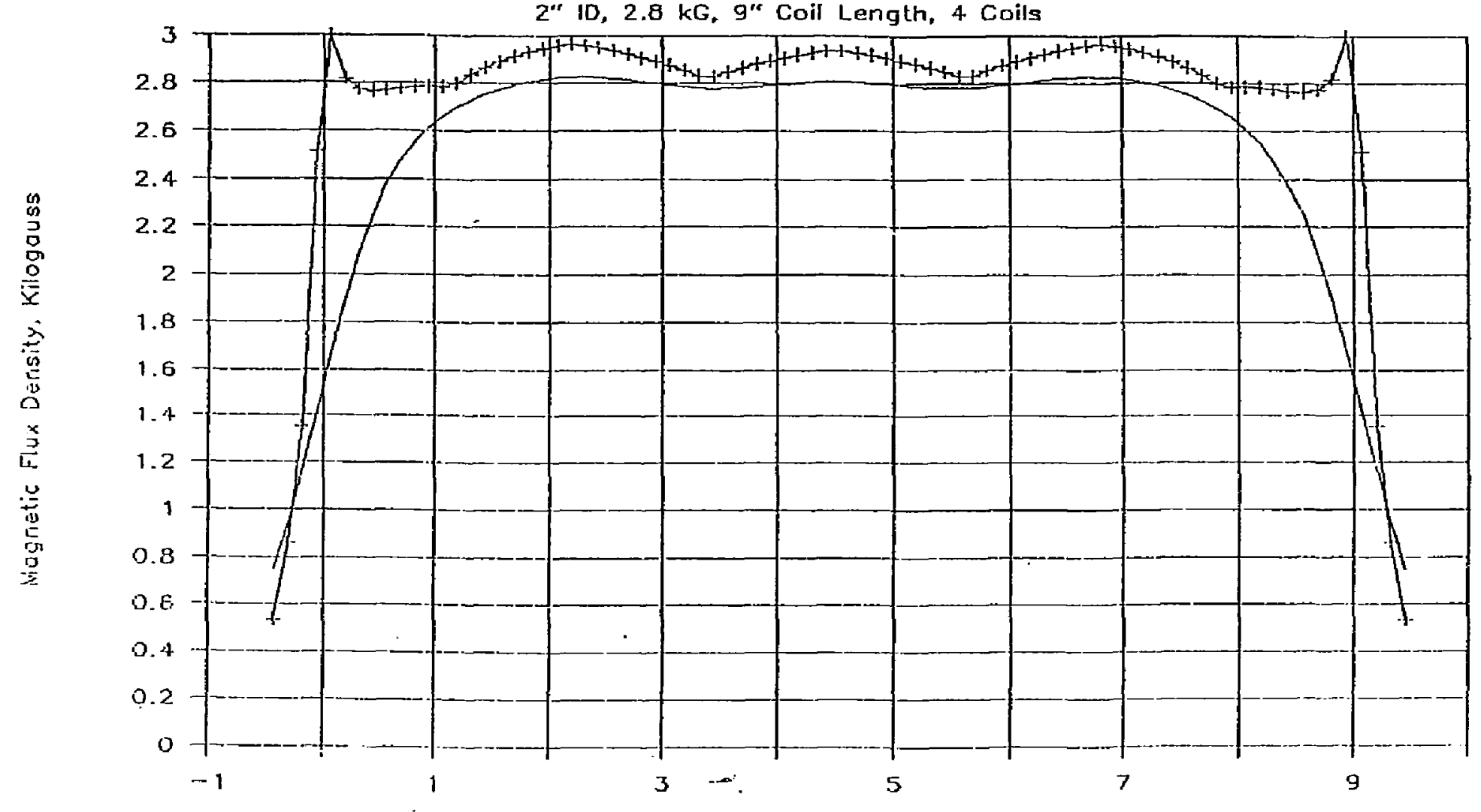

Distonce From Inside of Pole Piece. In. 


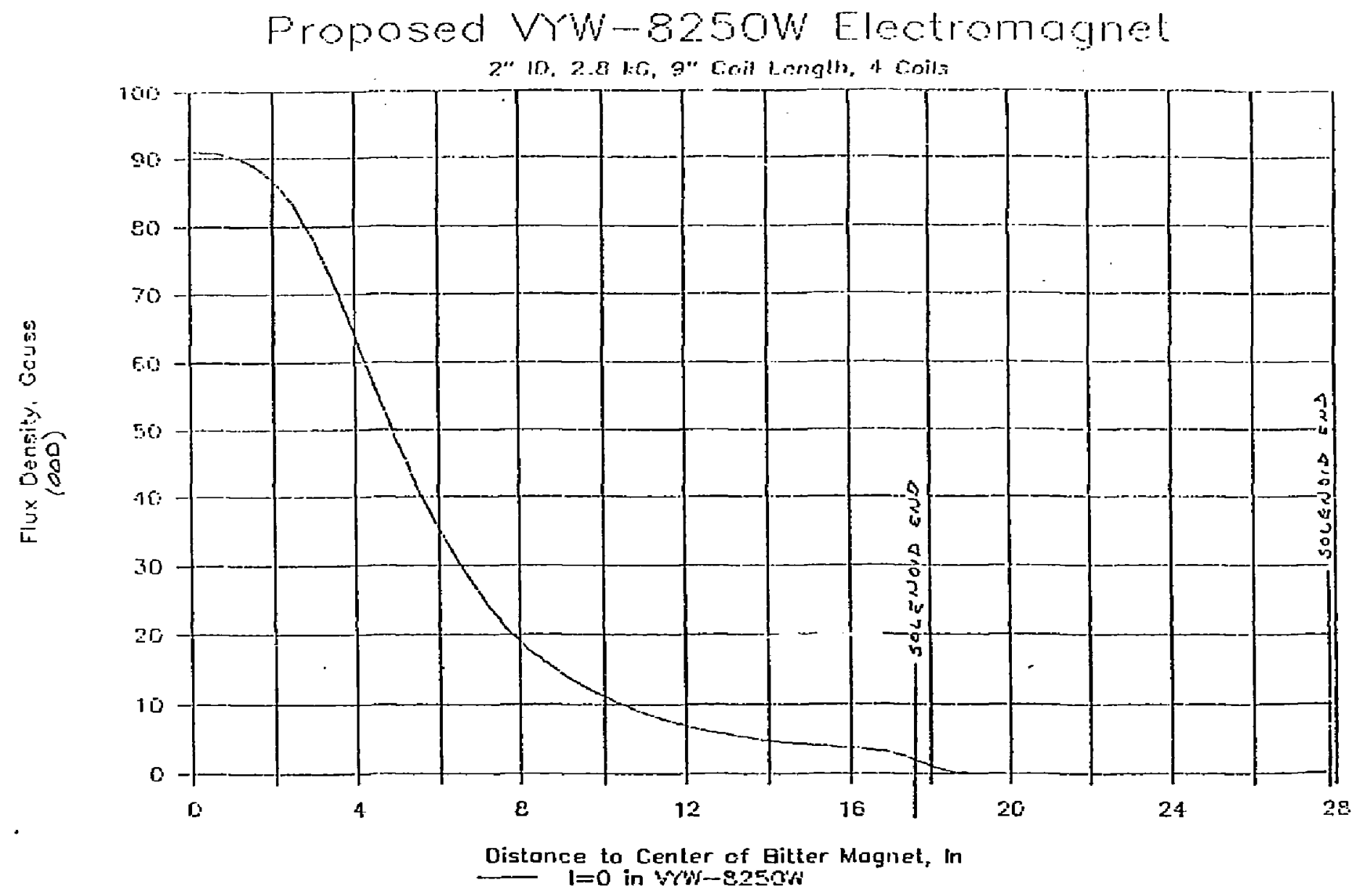




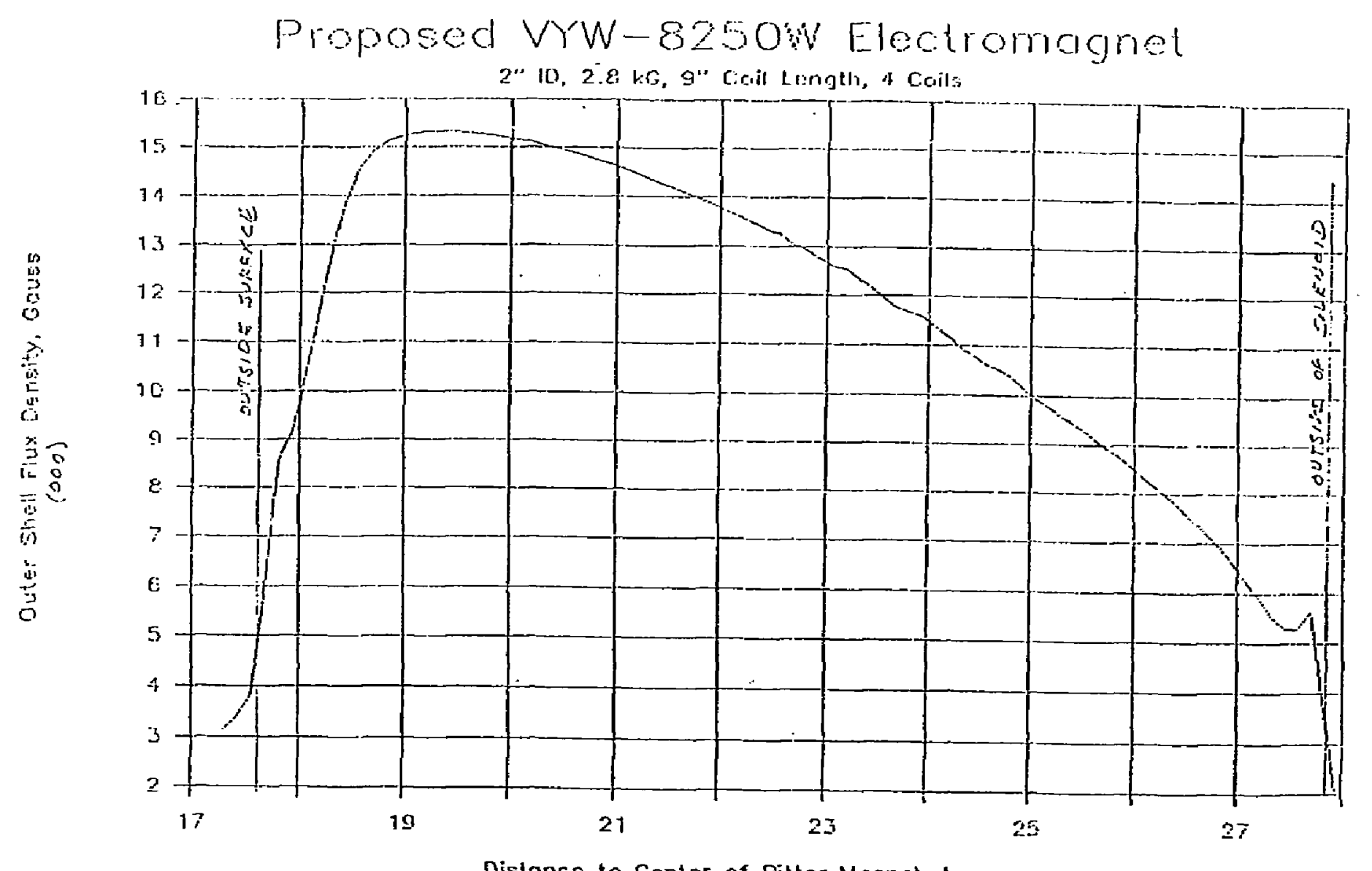

Distonre to Center of Bitter Magnet, In

$1=0$ in $V W-8250 w$ 
Proposed VW-8260h Electrongonel

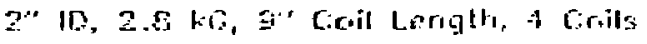

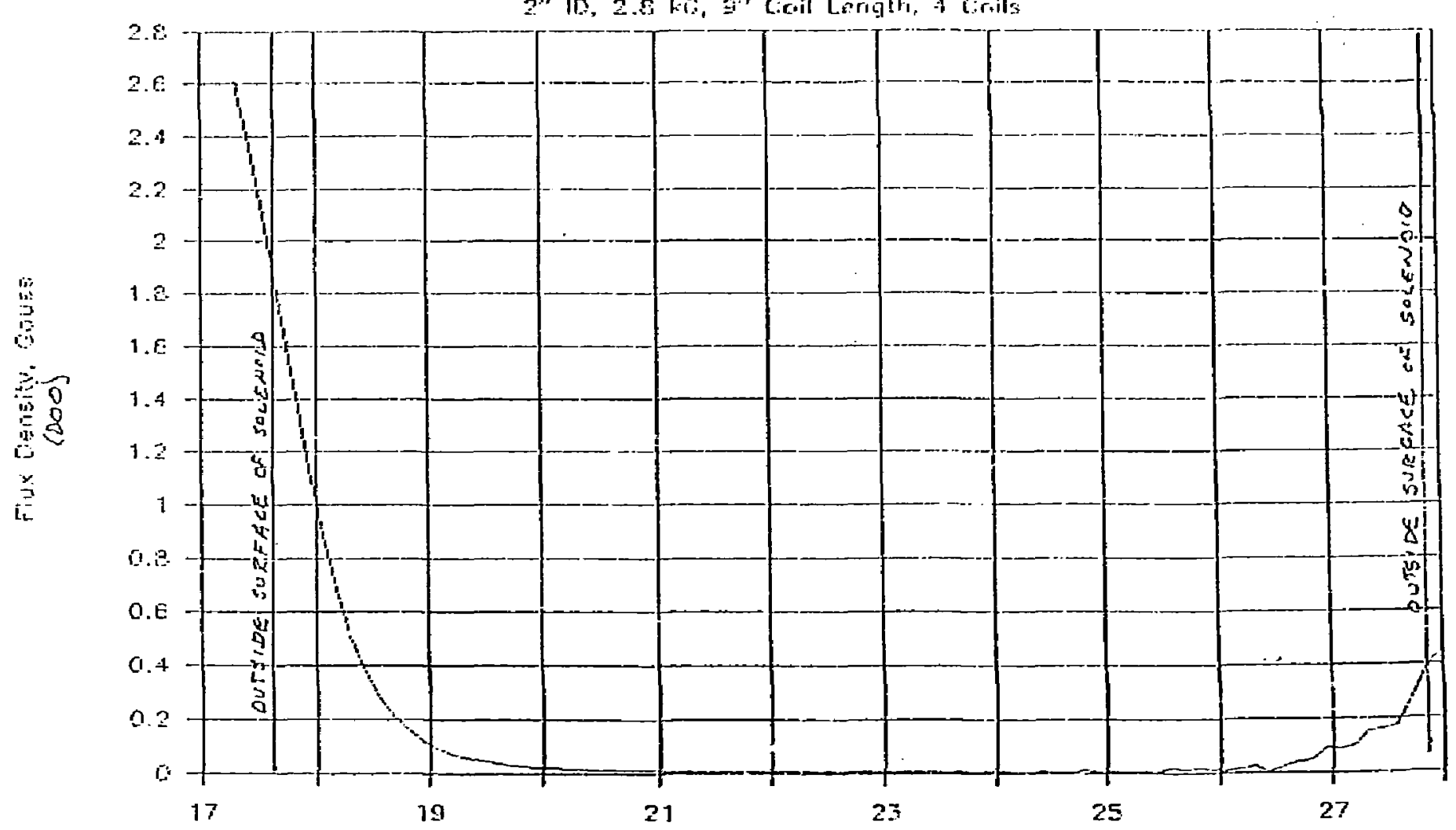

Cistonce to Cerife: of Bitter Mognet, In 


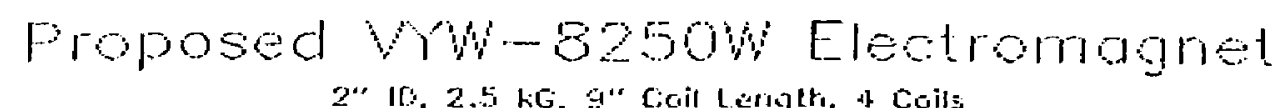

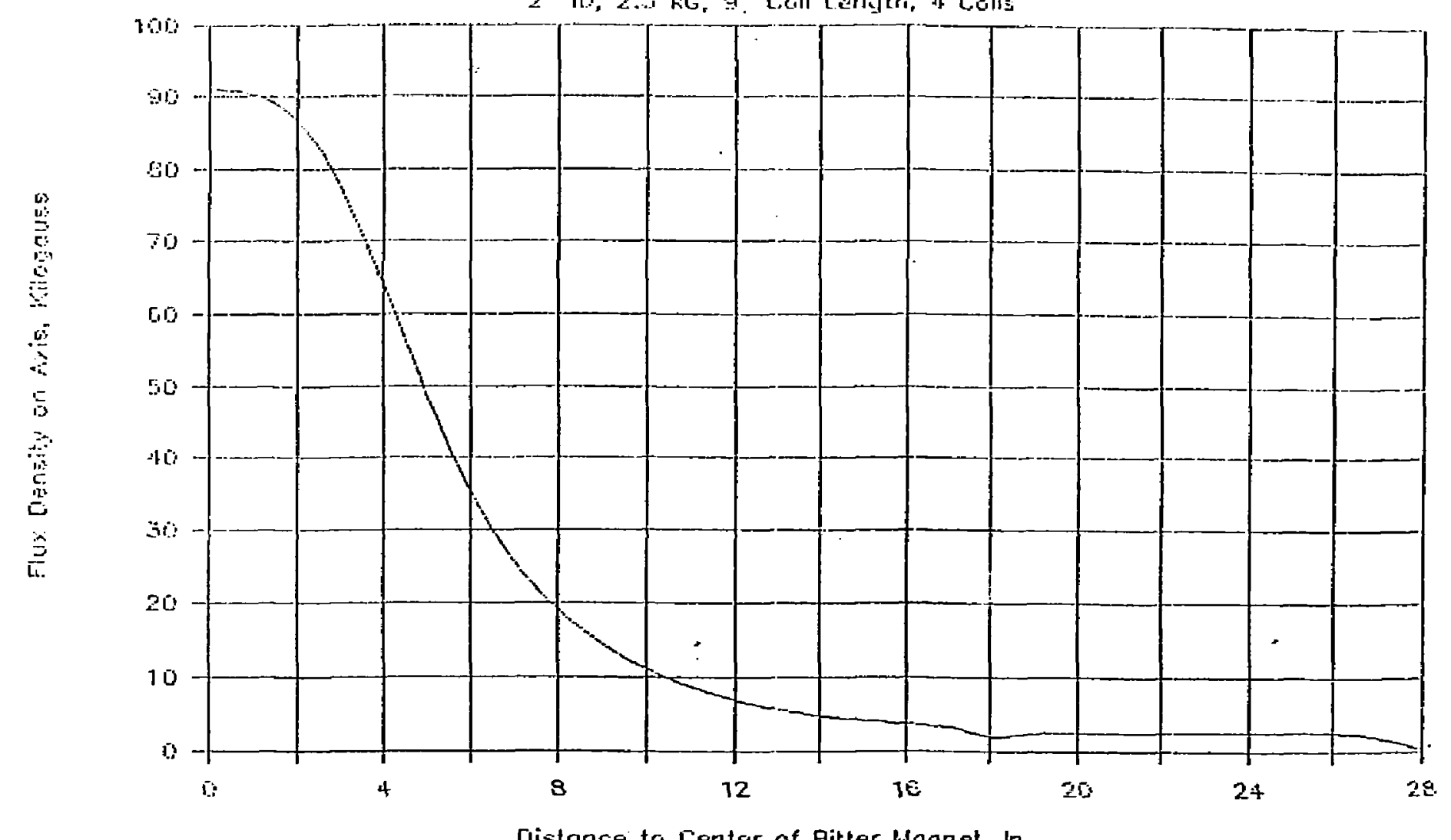

Distance to Center of Bitter Magnet, in 


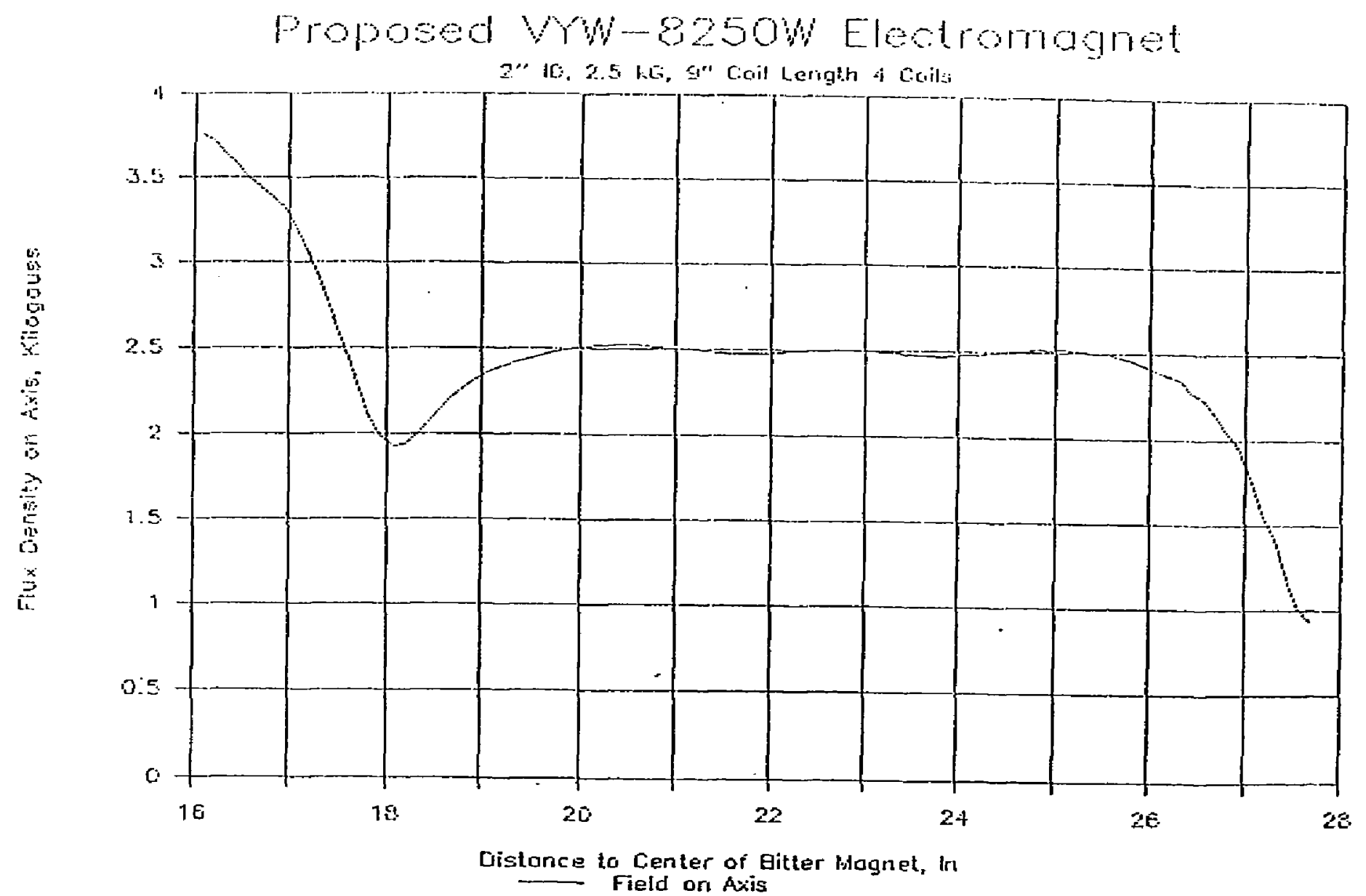




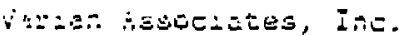

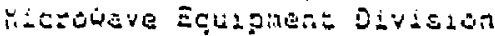

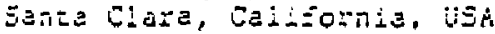

0105032 is, Rev i Hocel VYW-8250W

E. D. - .

- Fepruaty 25, 1588

TENTCTEVE SPECIEICATIOH

rodel Vy-B2juid Elsctromagnet

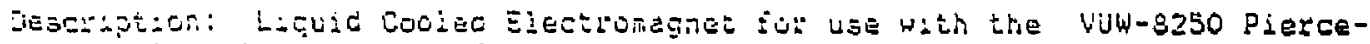

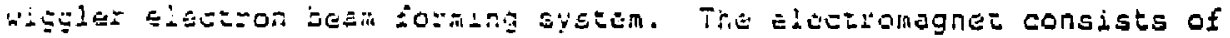

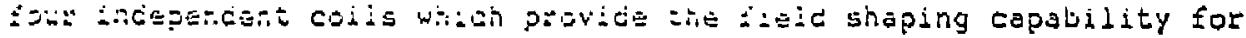
2.0.

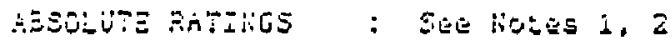

\begin{tabular}{|c|c|c|c|c|c|c|c|c|c|}
\hline 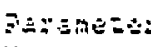 & 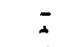 & $T( \pm .7)$ & 0 & 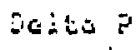 & $?$ & जil $(20)$ & $22(20)$ & $5.3(20)$ & $R 4(20)$ \\
\hline $\ln :=5$ & ric & し & 3? & poic & 0515 & Ofons & Ohlis & Ohms & Ohms \\
\hline & $5 \vdots$ & 35 & $:$ & 20 & S" & & 0.293 & 0.293 & \\
\hline
\end{tabular}

Noses : i:

$\&, s \quad s$

3

3

3

3

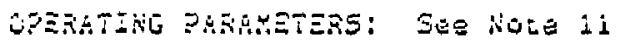

\begin{tabular}{|c|c|c|c|c|c|c|c|}
\hline Saramater & & $I i, i$ & {$[2.3$} & iopl & 50 2 2 & nep 3 & Rop4 \\
\hline bin: & : & $\begin{array}{l}\text { ñce } \\
-\end{array}$ & hoc & Oins & $\begin{array}{l}\text { Eting } \\
\text { - }\end{array}$ & Ohas & Ohms \\
\hline 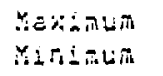 & : & 51.47 & 47.82 & 0.376 & 0.367 & 0.367 & 0.376 \\
\hline iEたS & : & $: 0$ & 4 & 4 & 4 & 10 & 4 \\
\hline
\end{tabular}

Jinisisichs

: Pen Cutidne Dáawing Ko.

TED

Youstrg Posizion : Any

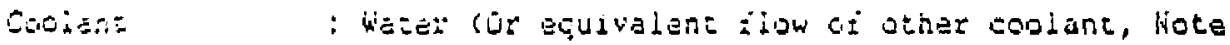
3 and $\bar{y}$

tลas:

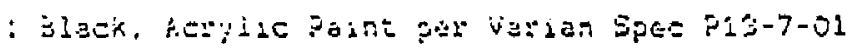

WE:

: 200 Lis

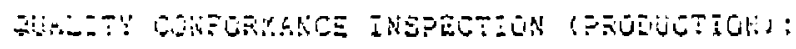

\begin{tabular}{|c|c|c|c|c|c|}
\hline †シミこ & Conditions & kin & $\ln 3:$ & Units & Notes \\
\hline 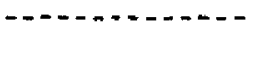 & 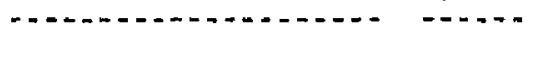 & -- & $\cdots$ & $\cdots+\infty$ & $\cdots-$ \\
\hline 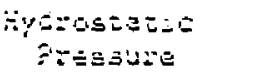 & $\begin{array}{l}\text { Ouliat closed, zou peig } \\
\text { cppited, } 5 \text { manutes (in:n) }\end{array}$ & liu LEakis & & & 7,3 \\
\hline$\because \because E s u r=D E 0 p$ & 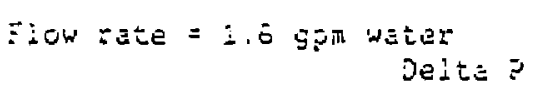 & & 50 & psid & 9 \\
\hline
\end{tabular}




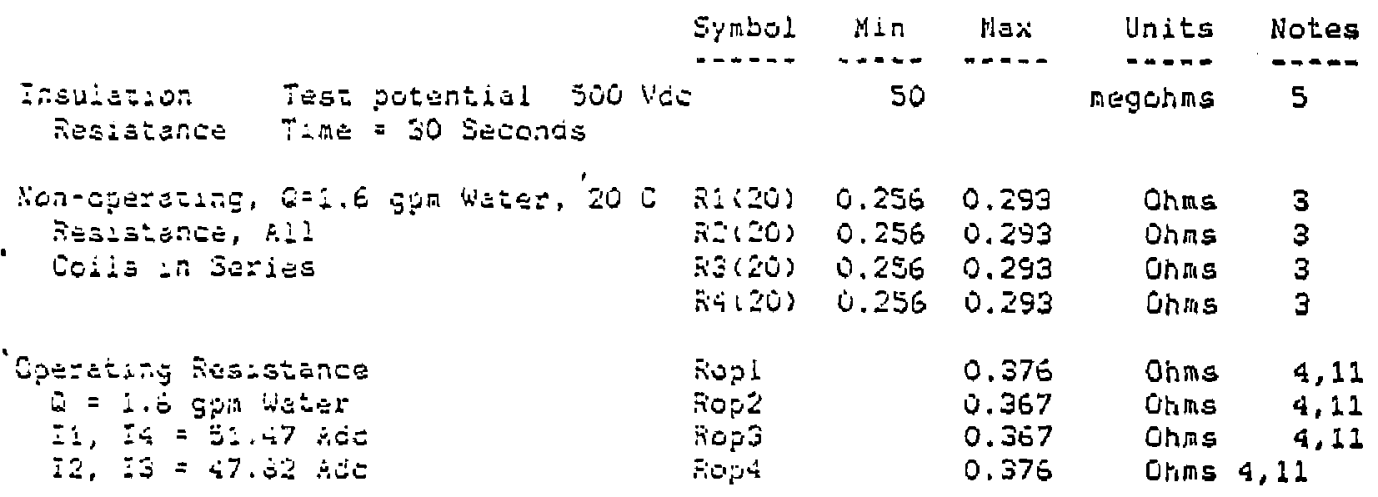

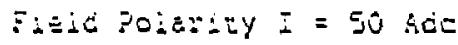

Aiding

6

$\therefore$ ese:

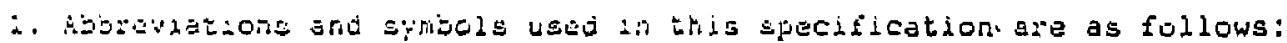

$$
\begin{aligned}
& I=\text { Openating cu:zan, acs (Hivmaers indicate coib) } \\
& D \text { = Hyorostatic piessule, psig }
\end{aligned}
$$

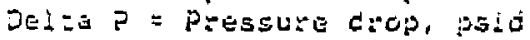

$$
\begin{aligned}
& Q=\text { Cooiant Elow rate, Gpa } \\
& \text { nizo) = hon-operaing "esistance corrected to } 20 \mathrm{c} \text {, ohms } \\
& \text { (Nulibets irdicate coil) } \\
& \text { Sug = opezzting cesistance, orms (Numbers indicate coil) } \\
& \overline{n i} \text { = kisn-opereting resistance, coils at } \\
& \text { temperature } T(i n) \text {, ohms } \\
& \text { (in) = Temperature of coolunt at inlet oi magnet, } C \\
& T \text {; Temperature et reasurement point } 1, C \\
& T 2 \text { = Tempersture at nesurement point } 2, C
\end{aligned}
$$

2. The merdnum ratings ere not to be exceeded under any sevvice conditlons. ipe:azon byyond these iacings will ghorten the service iffe and may lead to

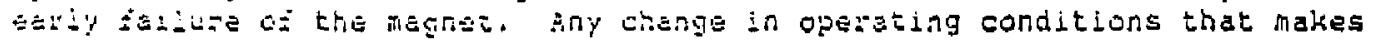
ine magiet operate at a lower tompe:ature (a.g. lower current, higher flow

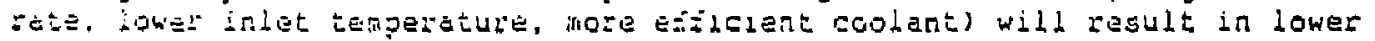
poner consumpton, longer servies dife and highoi reliability.

3. This "istsurentit is mace with coolant zlowing, but with no power applied to this eoils. When ine tempergture has stabilided, the resistance of the

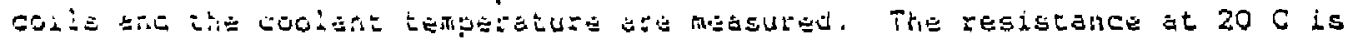

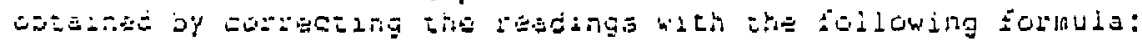

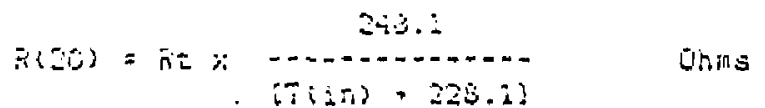

The resiscance of ine unit est be extrapoidied to eny tempexature, T2

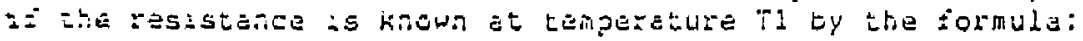

$$
\begin{aligned}
& (72 \cdot 233 . j]
\end{aligned}
$$

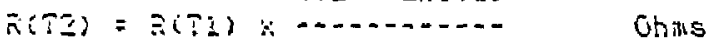

$$
\begin{aligned}
& \text { [T] } 238.1]
\end{aligned}
$$


$\therefore$ Tidi nessulesent is made with minimun soojant ilowing at the maximum inde : siperature and the lniclcated currents applied to the respective coida, When the wilt tis stabilized, the rojtage reading across the coils is E-vicec by thi cu:zent to cetermine the operating resistance. When opezasec in this node the tinit will not excegd the maximum resistance value

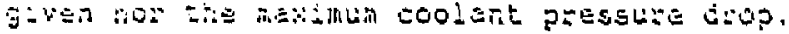

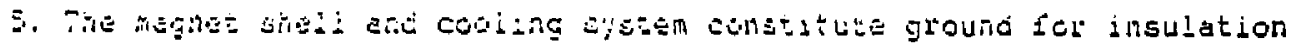

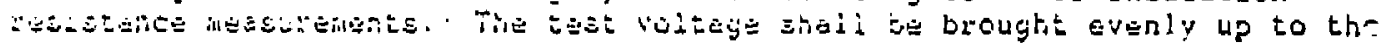

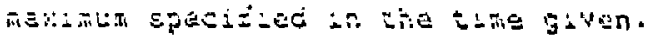

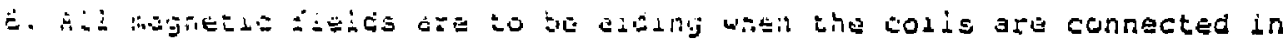
$\therefore: \therefore: D$.

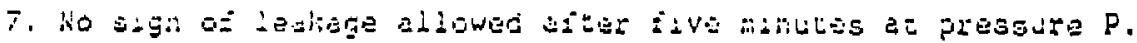

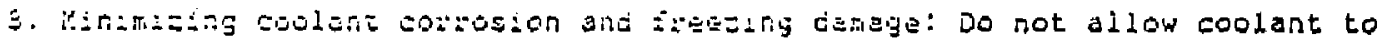

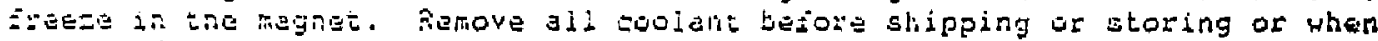

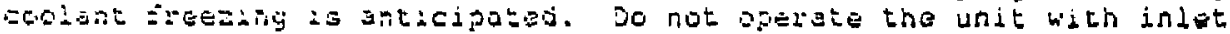

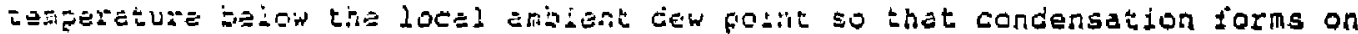
sie unit. It is secotinended that the mandm soolent flow rate be limited =5 iess than 2.5 jpli to prevent cavitution and resultant corrosion Ecesiaretion dut to high coolont veicodty. Fhall trachs of high purity

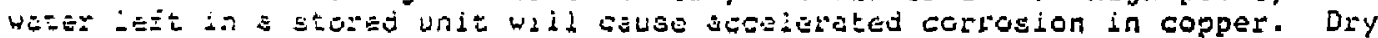

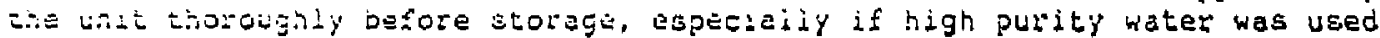

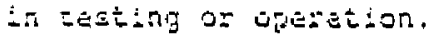

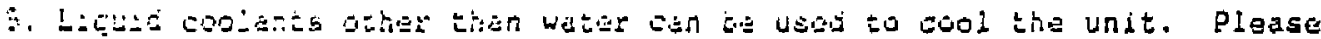

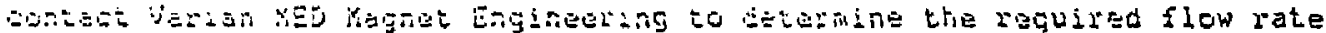

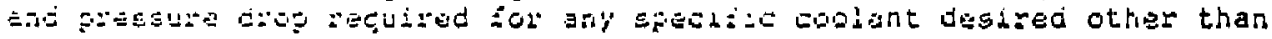
Ni.

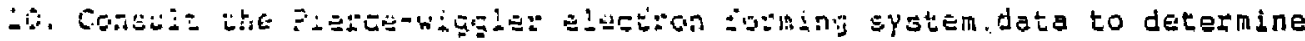
=u:

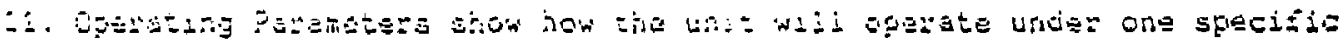

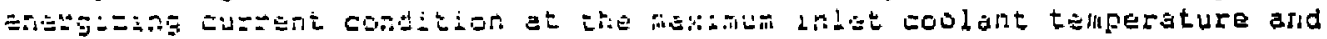

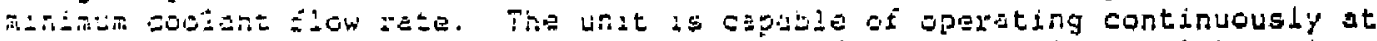
Ej jE

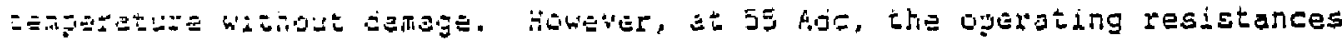
2:

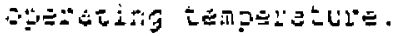

